\title{
SUSTAINABLE AGRICULTURE: A CASE STUDY ON THE PALM OIL INDUSTRY
}

\author{
Aikanathan. $S^{1 *}$, Chenayah. $S^{1}$ and Sasekumar. $A^{2}$ \\ ${ }^{1}$ Department of Economics, Faculty of Economics and Administration, ${ }^{2}$ Institute of Biological Sciences, Faculty \\ of Science, University of Malaya, 50603 Kuala Lumpur, Malaysia \\ * sarala.aikanathan@gmail.com (corresponding author)
}

Received on 5th February 2011, accepted in revised form 27th March 2011.

\begin{abstract}
The palm oil industry has long suffered criticism for destroying forest, wildlife and denying rightful ownership of land. To avert these persisting criticisms, the Roundtable on Sustainable Palm Oil (RSPO) was formed by a diverse group of stakeholders in the palm oil industry, to promote sustainable agriculture and address environment impact. Sustainability efforts begin from good environmental, social and agricultural practices: where the oil palm is first planted and grown to it final destination, the plate of a consumer or other products. The palm oil industry is the first to have certified sustainable produce, through the RSPO certification. The sustainability measurements are based on RSPO's 8 principles, 39 criteria, 126 indicators and guidance. The formation of the RSPO has not been without criticism from various sectors, especially the environmental NGOs. Sustainability in agricultural practises is no more an option, and agriculture need to feed the growing billions in the earth's population. The ever degrading environment needs protection and restoration. But, we can afford to fail with or without RSPO and other efforts by the industry similar to Malaysian Palm and Indonesian Sustainable Palm Oil should be given encouragement and support.
\end{abstract}

(Key Words: Agriculture, Palm Oil, Sustainable, Small Farmers, Life Cycle)

\begin{abstract}
Abstrak Industri kelapa sawit telah dikritik sejak dahulu kerana menyebabkan pemusnahan hutan, hidupan liar dan menghalang pemilikan tanah yang sah. Untuk mengatasi masalah-masalah ini, Roundtable on Sustainable Palm Oil (RSPO) telah diujudkan oleh kumpulan yang menpunyai kepentingan ke atas industri kelapa sawit bertujuan mempromosikan pertanian mapan dan menangani kesan-kesan negaif ke atas alam sekitar. Usaha-usaha pertanian mapan bermula dari amalan persekitaran, sosial dan pertanian yang baik; dari masa kelapa sawit mula ditanam kepada destinasi terakhir, iaitu pinggan pengguna atau produk lain. Industri kelapa sawit merupakan industri pertama yang memperolehi pensijilan hasil yang mapan, melalui pensijilan RSPO. Penilaian mapan adalah berdasarkan 8 prinsipal RSPO, 39 kriteria, 126 indikator dan petunjuk. Penubuhan RSPO juga telah menerima kritikan dari pelbagai sektor, terutamanya dari petubuhan-pertubuhan alam sekitar bukan kerajaan (NGO). Pertanian mapan bukan lagi merupakan suatu pilihan dan pertanian perlu untuk memenuhi keperluan penduduk bumi yang meningkat. Alam sekitar yang semakin dicemar, memerlukan perlindungan dan pembaikpulihan. Akan tetapi, kita mampu gagal dengan atau tanpa RSPO dan usaha-usaha lain dari industri yang menyerupai kelapa sawit Malaysia dan Indonesian Sustainable Palm Oil perlu diberi galakan dan sokongan.
\end{abstract}

(Kata kunci: Pertanian, Kelapa Sawit, Mapan, Petani Kecil, Life Cycle)

\section{INTRODUCTION}

There are many definitions of sustainable agriculture, organic farming, and ecological farming. Sustainable agriculture is characterised by managing the land as a living system in which the farmer/grower acts to support a dynamic balance among the plants, animals, insects, soil, and water. The essentials are seeing the land a living system embedded in a broader ecosystem and understanding how to manage all farm practices on the basis of this holistic perception.

The RSPO or the Roundtable on Sustainable Palm Oil has adopted the Brundtland definition and has placed efforts begins from good environmental, social and agricultural practices: where the oil palm is first planted and grown to it final destination, the plate of a consumer or other products.

A balanced society through Prescott-Allen's model, where social and economic factors are further emphasised through governance, human wellbeing and resources demands (Prescott-Allen, 2006), draws a wider rim around sustainability measures. A wider rim takes the farmers/growers into regional programs for water management, watershed conservation, rebuilding soil quality, ecosystem restoration, and reforestation. Thereby, all activities including agriculture needs to consider the whole human paradigm of sustainable management, and progress. 


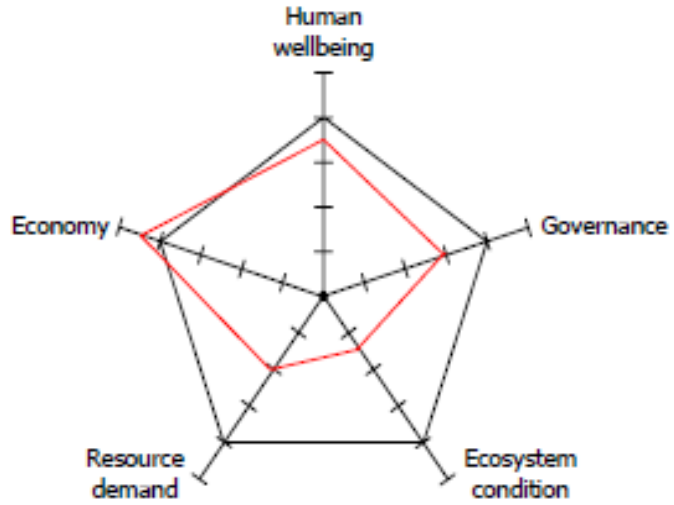

Figure 1: Graphic combination of 5 pillars

The philosophical and analytic framework of sustainability draws on and connects with many different disciplines and fields (Figure 1); in recent years an area that has come to be called sustainability science has emerged. Sustainability science is not yet an autonomous field or discipline of its own, and has tended to be problem-driven and oriented towards guiding decision-making.

\section{Sustainability Requirements}

Sustainable requirements for resource demand, ecosystem condition, governance, economy and human wellbeing are as below.
This example displays performance in each pillar on a 0 100 scale divided into five bands (0-20, 21-40, 41-60, 61-80, 81-100). 0 is at the centre. The 81-100 band is outside the pentagon and represents "good" performance. The thicker (red) line shows the performance scores of a hypothetical country: human wellbeing 68 , economy 88 , governance 59 , resource demand 40, and ecosystem condition 28(PrescottAllen, 2006).

\subsection{Resource Demand}

The world population has grown tremendously over the past two thousand years. In 1999, the world population passed the six billion mark. Latest world population estimate are 7 billion people by mid-year 2009. As the world's appetite for edible oils grow, fuelled by demand for everything from food to detergents, it is very apparent from Figure 2, the need for edible oils will continue to increase.

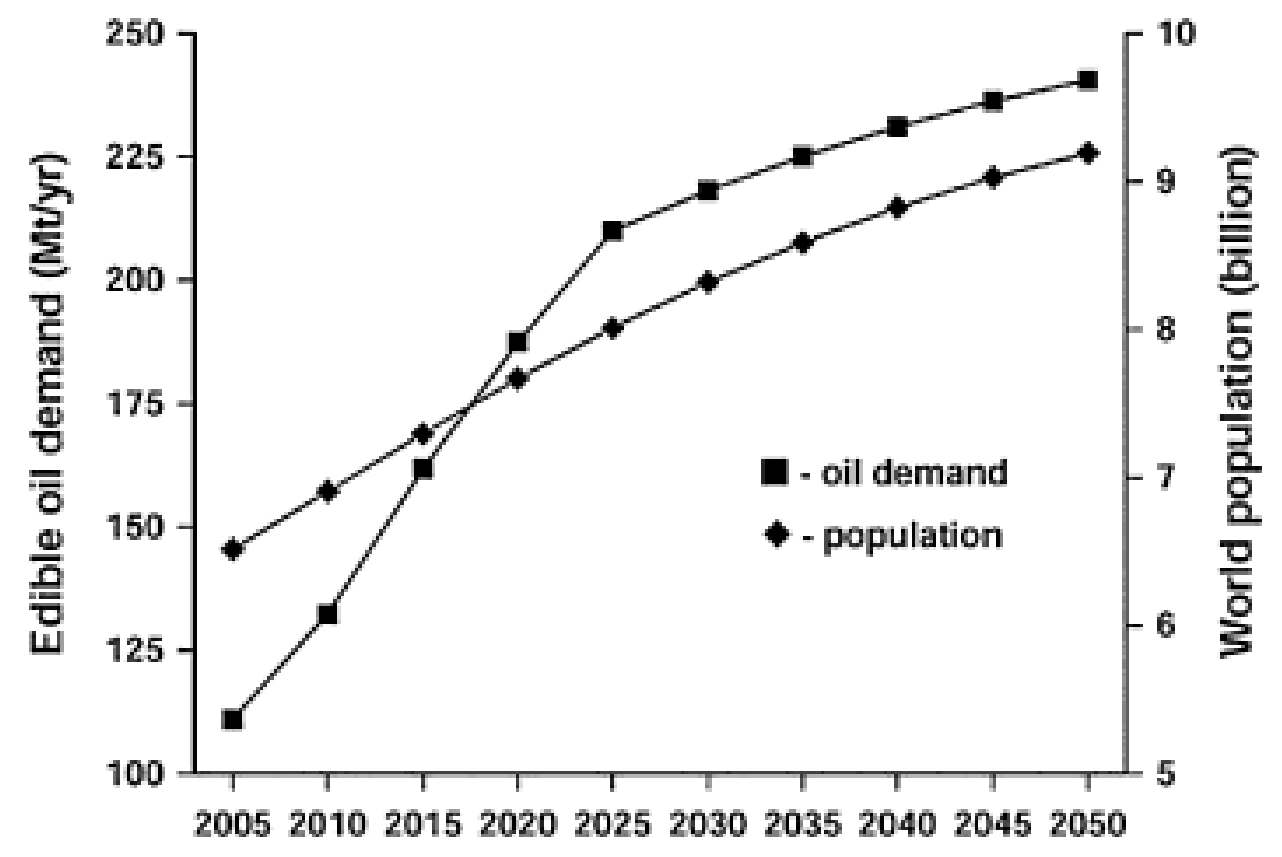

Figure 2: Expected trends in world population and edible use of vegetable oil. Population from UNDP(2006) 
Almost, $30 \%$ of the world's edible oil supply comes from 1 crop, palm oil and this high-yielding crop is critical to the world's food and possibly energy supply. Over 2 million people derive their livelihood from this crop, and it generates over $\$ 200$ billion dollars in revenues (Aikanathan et al., 2011). In the two countries responsible for over $80 \%$ of world oil palm production, Indonesia and Malaysia, smallholders account for $35-40 \%$ of the total area of planted oil palm and as much as $33 \%$ of the output. Elsewhere, as in West African countries that produce mainly for domestic and regional markets, smallholders produce up to $90 \%$ of the annual harvest.

At the same time, the large-scale deforestation and harm caused to the environment has raised the concerns of consumers and Non-Government Organizations (NGOs) across the world. This pressure created lots of friction between producers and NGOs. The earth is under threat from a growing population and scarce natural resources, and sustainable agriculture is a means of balancing the environmental degradation (Sheil et al., 2009).

\subsection{Ecosystem Condition}

According to UNEP (UNEP, 2007), at the current rate of intrusion into South-east Asian's protected rain forests will be severely degraded by 2012 through illegal hunting and trade, logging, and forest fires, including those associated with the rapid spread of palm oil plantations. Palm oil production has been documented as a cause of substantial and often irreversible damage to the natural environment. Its impacts include: deforestation, habitat loss of critically endangered species such as the Orang Utan and Sumatran Tiger.

Southeast Asia's annual deforestation rate the highest in the tropics, this could result in projected losses of $13-85 \%$ of biodiversity by 2100 . Secondary habitat restoration, at least in certain countries, would allow for some amelioration of biodiversity loss and thus potentially lower the currently predicted extinction rates. Nonetheless, urgent conservation actions are needed. Conservation initiatives should include public education, sustaining livelihoods, and ways to enhance the sustainability of agriculture and increase the capacity of the local communities (Sodhi et al., 2008).

However, oil palms are highly efficient producers of oil, requiring less land than any other oilproducing crop (Figure 3). Some oil palm plantations yield more than 6 tonnes of oil per hectare per year (Jothiratnam, 2010).

\title{
Oil palm: 3.68
}

Rapeseed: 0.59

\author{
Sunflower: $\mathbf{0 . 4 2}$
}

\section{Soybean: $\mathbf{0 . 3 6}$}

Figure 3: Average yield per year (tonnes of oil per hectare) (Source: RSPO, 2008) 


\subsection{Governance}

There many levels of governance flow in the palm oil industry. It can come through the company that manages the industry, such as Sime Darby or Willmar International. Or through the local government and its' agencies such as Malaysian Palm Oil Council and Malaysian Palm Oil Board in Malaysia while through Indonesian Palm Oil Commission and the Indonesian Palm Oil Council.

Association related governance for the industry is also directed through voluntary acceptance through NGOs like the RSPO, GAPKI (Indonesian Palm Oil Association - Gabungan Pengusaha Kelapa Sawit Indonesia) and MPOA (Malaysian Palm Oil Association).

Due to the multi-faceted governance structure in the palm oil industry, the industry especially in South-east Asia has move leaps and bounce in improving it productivity, research and sustainability efforts. However, as the governance influences come from different levels and directions there are also confusion and redundancy in the sector.

\subsection{Economy}

The theory of ecologically unequal exchange posits, that through the vertical flow of exports from less-developed countries, the stratified world economy enables more-developed countries to externalize their environmental costs. It is further argued that this externalization of environmental costs increases forms of environmental degradation within the borders of less-developed countries. Additional results indicate that deforestation is positively associated with total population growth and negatively associated with both economic development and the presence of environmental international non-governmental organizations (Jorgenson et al., 2010).

The concept model of (Leahy, 2010) provides insight into how social capital is linked between multiple entities within this context. The study findings expand on the current understanding of social capital and suggest ways researchers might approach future studies of social capital in similar settings. The findings have natural resource management implications, including ways of focusing management, increasing public involvement, and facilitating communication approaches.

Despite Indonesia diversifying away from food crops, food insecurity there declined by nearly 60 per-cent from 1981 to 2007, driven largely by increased food access and higher incomes (Rada,
2010). Indonesia boosted food availability through agricultural growth and food imports, but increasing food availability was not the sole factor contributing to its improved food security. Indonesia's expansion of food accessibility through greater consumer purchasing power and mobility of goods and services likely has played a significant role.

Expansion in agriculture activities and other government expenditure in a country are planned in view of GDP, and The Gross Domestic Product (GDP) or Gross Domestic Income (GDI) is the amount of goods and services produced in a year, in a country. The appropriateness of GDP to evaluate the status of a country was challenged by the Human Development Index developed by Haq in 1990. The Human Development Index (HDI) is a composite statistic used to rank countries by level of "human development" and separately developed (high development), developing (middle development), and underdeveloped (low development) countries. The statistic is composed from data on life expectancy, education and percapita GDP (as an indicator of standard of living). The HDI has been used since 1990 by the United Nations Development Programme for its annual Human Development Reports.

All these economic tools are being deliberated to evaluate its' robustness in setting an appropriate management model for the palm oil industry.

\subsection{Human Wellbeing}

A measure of human development using three equally weighted dimensions of human development - life expectancy at birth, adult literacy and mean years of schooling and income (purchasing power per capita in dollars). HDI is an attempt to make 'fairer' but still statistical measurements of development that became popular at the UN in the 1990s, and had assigned value between 0 and 1 according to ranking position for each of the factors of purchasing power of income, literacy rate and longevity (Haq, 1990).

Human mobility and trans-boundary changes report (Haas, 2009) pointed out the extraordinarily unequal global distribution of opportunities and how this is a major driver of the movement of people. Our main message is that mobility has the potential to enhance human development among movers, stayers and the majority of those in destination societies. However, processes and outcomes can be adverse, sometimes highly so and there is therefore scope for significant improvements in policies and institutions at the national, regional and international levels. Our core 
package calls for a bold vision and identifies an ambitious long-term agenda for capturing the large unrealized gains to human development from current and future mobility

This field of studies is also called "The economy of happiness". The Satisfaction with Life Index is an attempt to show the average self-reported happiness (subjective life satisfaction) in different nations. This is an example of a recent trend to use direct measures of happiness, such as surveys asking people how happy they are, as an alternative to traditional measures of policy success such as GDP or GNP. Some studies suggest that happiness can be measured effectively.

However, a free market think tank Cato Institute points out that since life expectancy has continued to increase in nations wealthier than this, often partly attributed to economic growth, Happy Life Years have continued to increase. It has been argued that happiness measures could be used not as a replacement for more traditional measures but as a supplement.

\section{The Concept of Roundtable}

The Roundtable Sustainable Palm Oil (RSPO) was formed by a diverse group of stakeholders in the palm oil industry, to promote sustainable agriculture and address the environmental impact of palm oil. This association was formed in 2004 , in this way, RSPO lives out the philosophy of the "roundtable" by giving equal rights to each stakeholder group to bring group-specific agendas to the roundtable, facilitating traditionally adversarial stakeholders and business competitors to work together towards a common objective and making decisions by consensus (Aikanathan, 2010).

Similar initiatives have been in established for other sectors, and they include: Roundtable on Sustainable Biofuel; Roundtable on Sustainable Forest; Roundtable on Sustainable Development; Roundtable on Responsible Soy; Roundtable on Sustainable Cocoa Economy. All these initiatives have similar motives in trying to drive industry and agriculture towards sustainable way of practises.

\section{What is Sustainable Palm Oil?}

Sustainability efforts begin from good environmental, social and agricultural practices: where the oil palm is first planted and grown to it final destination, the plate of a consumer or other products. And the palm oil industry is the first to have certified sustainable produce, through the RSPO certification. And the sustainability measurements are based on RSPO's 8 principles, 39 criteria, 126 indicators and guidance. These standards address the legal, economic, environmental and social requirements of producing sustainable palm oil (RSPO, 2010).

RSPO's Principles and Criteria (P\&C) for sustainable palm oil production are based on these principles: commitment to transparency; compliance with applicable laws and regulations; commitment to long-term economic and financial viability; use of appropriate best practices by growers and millers; environmental responsibility and conservation of natural resources and biodiversity; responsible consideration for employees and for individuals and communities affected by growers and mills; responsible development of new plantings; and commitment to continuous improvement in key areas of activity.

\subsection{Other Sustainable Palm Oil Initiatives: Malaysia and Indonesia}

The following section explains sustainable palm oil initiatives in Malaysia and Indonesia.

\subsubsection{Malaysian Palm Oil or Malaysian Palm}

In 2008, Malaysia produced 17.7 million tonnes of palm oil on 4,500,000 hectares and was the second largest producer of palm oil, employing more than 570,000 people. Malaysia is the world's second largest exporter of palm oil. About $60 \%$ of palm oil exports from Malaysia are shipped to China, the European Union, Pakistan, United States and India. They are mostly made into cooking oil, margarine, specialty fats and oleo chemicals.

With the current need to meet the sustainability challenges and also ensure future acceptance of the palm oil, the Malaysian government with MPOC, MPOB and SIRIM (a Malaysian research and standards development organization) have embarked to produce a "Malaysian brand" sustainable palm oil for the consumers. This effort has received much applause from the consumer and producer nations including Indonesia, India and China.

\subsubsection{Indonesian Palm Oil or Indonesian Sustainable Palm Oil (ISPO)}

As of 2009, Indonesia was the largest producer of palm oil, surpassing Malaysia in 2006, producing more than 20.9 million tonnes. The Indonesian aspires to become the world's top producer of palm oil. FAO data show production increased by over 400\% (year: 1994-2004) to over 8.66 million metric tonnes. 
The Indonesian government now have their own scheme for sustainable palm oil production. The Indonesian Sustainable Palm Oil [ISPO] scheme is designed to make palm oil production sustainable in compliance with Indonesian laws and regulations. Several executives from the Indonesian Palm Oil Producers Association (GAPKI) and the government-sponsored Indonesian Palm Oil Board are assisting in the Indonesian government in its sustainability scheme. Indonesian Palm Oil Commission has waived the fees for ISPO certification for small- and medium-size companies and smallholders, who make $40 \%$ of the production volume.

\section{Sustainable Palm Oil Trade}

Palm oil makes up about $30 \%$ share of the edible oils traded and consumed around the world today. It has been estimated that 40 million tonnes of palm oil was traded in 2008. Late 2009, about 1.5 million tonnes of certified sustainable palm oil was produced through the RSPO system, which is currently the only one available for palm oil.

Certified sustainable palm oil is traded in one of the following four ways: Identity Preserved, Segregation and Mass Balance. Under "Identity Preserved" the oil can be traced back to the specific plantation in which it has been cultivated and produced. Under "Segregation" sustainably produced palm oil is kept separate from the nonsustainably produced oil all through the value chain.

The "Mass Balance" should be regarded as an intermediate model towards Segregation, allowing supply chain companies to gradually prepare for segregated trading. In this model the certified physical oil is allowed to be mixed with conventional oil throughout the supply chain, while allowing specific sustainability claims. It is a step towards full segregation, making use of the same administrative systems as are applicable for Segregation. The certification group UTZ CERTIFIED have developed a system for tracking certified sustainable palm oil. Since the inception of RSPO, the association has been striving for the palm oil industry to be sustainable through-out its' life cycle; from the palm to the plate or end-user.

\subsection{Fair Trade, Affordability and Economy}

If sustainability is to be achieved, it has to happen in the market sector. This means that sustainability needs the support of market players, such as companies and producers. And it must be reinforced by market processes, such as pricing which reflects social and ecological costs of production and environmental values (Fairtrade Foundation, 2010).

A sustainable market depends on the interaction between three parties: companies committed to sustainable practises, good governance by governments and involvement of civil society organizations with firm grounds in society. When all the stakeholders in the chain play their part, sustainable trade flows occur. This is current lacking in the sustainability life-cycle, and only the growers/producers seem to hold the cost of the challenge. SOLIDARIDAD, a non-profit organization engages the supply chain at every stage, from farmer to consumer to stimulate fair trade. The fair trade activities stimulated by SOLIDARIDAD are depicted in the Figure 4 (Solidaridad, 2010).

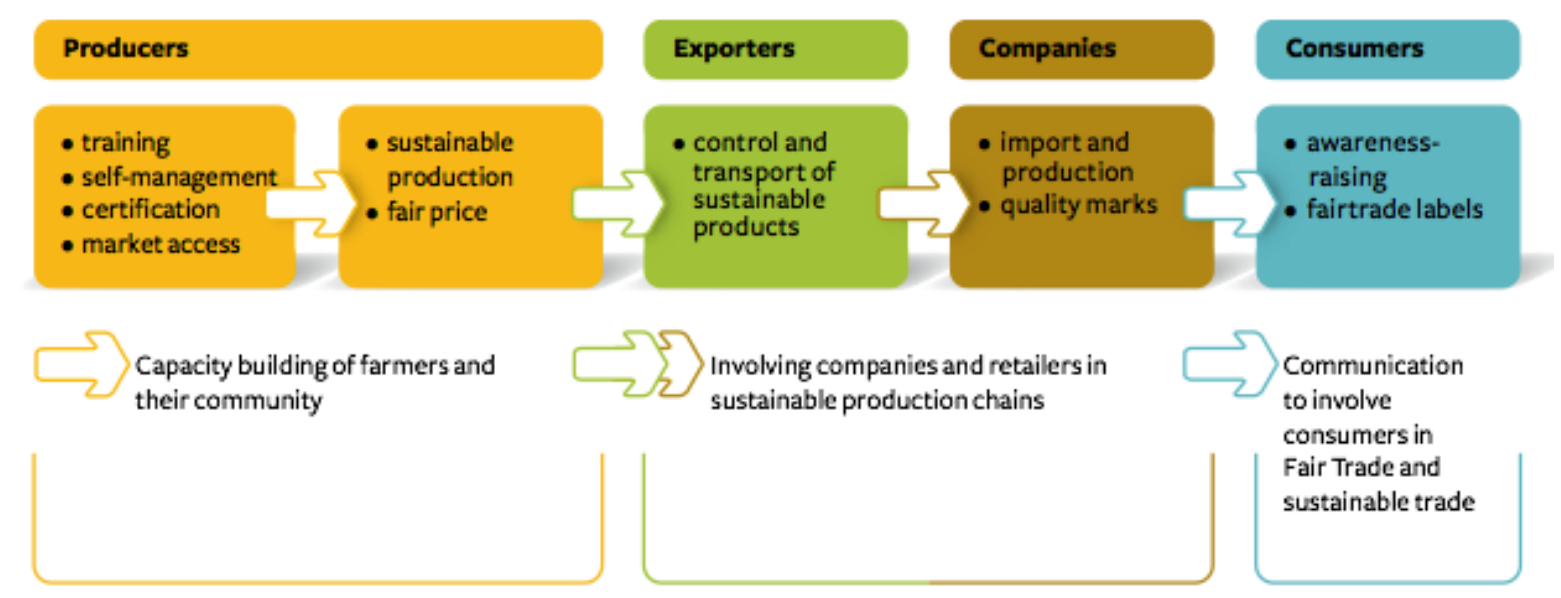

Figure 4: Sustainable supply chains (Solidaridad, 2010). 


\subsection{NGOs, Other Stakeholders and the RSPO}

The RSPO stakeholders for the palm oil life-cycle from the palm to user consist of growers/producers, traders and processors, banks and financial institutions, manufacture, retailers, social NGOs and environmental NGOs. However, government, media and consumers are not part of this cycle, thus causing disparity within the industry, and the acceptability of the current sustainability venture.

Both governments and associations like the RSPO and GAPKI need to cooperate to ensure the sustainability efforts bite. For all the principles and criteria will have not hold water if supporting government policies are not in place.

Then, there are the NGOs like Greenpeace, Rainforest Network and the Friends of the Earth International (FOEI) that are extremely critical of the palm oil industry and play a watch dog role over RSPO.

A recent investigation by Greenpeace found worrying issues with one of palm oil buyers' main palm oil suppliers and Greenpeace is working with the buyers together to lobby for a moratorium on deforestation for palm oil (Greenpeace, 2010).

\section{Criticisms, Gaps and Controversies}

The formation of the roundtable concept has not been without criticism from various sectors, especially the environmental NGOs.

\subsection{The Roundtable Concept}

The main issues flagged under this concept include: the impact of palm oil plantation expansion on the Orang Utan population; destruction of tropical forest for the new oil palm plantation schemes in South-East Asia; the burning and draining of large tracks of peat swamp forest in Kalimantan, Indonesia.

Most palm oil is produced by large corporate groups that own hundreds of thousands of hectares of oil palm plantations. The current concept does not require all producers to get the entirety of their estate certified at once. Companies need to have a 'realistic and adequately' ambitious plan for certifying their other plantations, if they have ownership of more than $51 \%$ of that plantation, and there are no set a timeline for this, Members can avoid taking any steps towards the certification of their land.
There is no permanent monitoring body. Only when there is a written complaint a grievance panel is established to conduct investigative research and provide recommendations for action by the RSPO.

\subsection{Understanding Tropical Biodiversity}

In the article: "Have we overstated the tropical biodiversity crisis? Laurance reviews again if we have overstated the tropical biodiversity crisis? His work is supported by the vigorous debate following a study by Wright and Muller-Landau that challenges the notion of large-scale tropical extinctions, at least over the next century. Laurance (2007) describes this controversy and how the debate is stimulating a serious examination of the causes and biological consequences of future tropical deforestation.

Therefore, any meaningful success in tropical conservation will, hence, need active collaboration by the civil society, biologists, social scientists, and lawyers, funding agencies, national and multinational corporations, governments and nongovernmental organizations. Concerted research efforts are urgently needed to understand the imperilled tropical biodiversity (Sodhi, 2008).

\subsection{Scientific Tools and International Standards:}

Scientific tools and standards, such as ISO are important in international trade because incongruent standards can be barriers to trade, giving some organizations advantages in certain areas of the world. Scientific tools and Standards provide clear identifiable references that are recognized internationally and encourage fair competition in free-market economies. Standards facilitate trade through enhanced product quality and reliability, greater interoperability and compatibility, greater ease of maintenance and reduced costs.

In applying the ISO International Standards, accounting of GHG mitigation and adaptation efforts in reduction of emissions requires two key areas to be addressed; firstly, what ISO GHG International Standards be used? And secondly, when incentivising the beneficial climate change mitigation practices care should be made to avoid any potential conflict with the World Trade Organisation (WTO) rules. Finally, the issue of cost in measuring, reporting and verifying (MRV) of climate change mitigation and adaptation activities must be matched hopefully with premium prices.

Alijosja et al.,(2006) estimated that the production of 1 tonne of oil palm on fully-drained peatland can result in $\mathrm{CO}_{2}$ emissions of 10-30 tonnes due to peat 
oxidation. However, various greenhouse (GHG) emission reduction gas savings values for palm oil have been reported by different researchers due to the different methodologies and approaches used in life cycle assessment. Such differences could be significant, ranging from $19 \%$ to as high as $80 \%$. This has made it very difficult for international authorities/agencies drafting biofuel legislations and standards to find a consensus for a universally accepted value for palm oil and other oilseed crops' greenhouse gas emission reduction savings. Scientists and practitioners have been logger head to put the best number for practice. Overcoming assumption barrier and over-sight is vital for the future placement of values in the palm oil Industry (Yew et al., 2010b).

\subsection{Lack of Data for Sustainability Challenges}

There has been a perpetual need to meet the challenges that are met by growers and producers to implement practices that will make the production palm oil economically viable and sustainably acceptable. The London Zoological Society (LZS), have initiated a web-portal (Persey and Anhar, 2010) to assist planters and growers to undertake proper planting and agricultural practises. A database for users on biodiversity information has been set-up by the LZS for this purpose.

An Assessment Tool and Integrated Index for Sustainable Oil Palm Production have shown the need to define and implement social responsibility and sustainable benchmarks. They have proposed the adaptation of a 'System for Weighted Environmental Impact Assessment in Oil Palm Production' (APOIA-Oil Palm) (Rodrigues et al., 2010). The present document reports on the conceptual basis, the methodological adaptation and the validation field trials carried out for consolidation of the proposed APOIA-Oil Palm sustainability index. The experience attained in the development and international negotiation of this proposed sustainability index, dedicated to such an important productive sector such as that of palm oil, can be instrumental for other environmental management and agriculture produce.

\subsection{Land Assignments and Changing Boundaries}

Projected conservation risk, measured as regional levels of land-cover change in relation to area protected, is the greatest at high latitudes (due to climate change) and tropics/subtropics (due to land-use change). Only some high-latitude nations prone to high conservation risk are also of high conservation value, but their high relative wealth may facilitate additional conservation efforts. In contrast, most low latitude nations tend to be of high conservation value, but they often have limited capacity for conservation which may exacerbate the global biodiversity extinction crisis (Lee and Jetz, 2008).

While our approach will clearly benefit from improved land-cover projections and a thorough understanding of how species range will shift under climate change, our results provide a first global quantitative demonstration of the urgent need to consider future environmental change in reservebased conservation planning. They further highlight the pressing need for new reserves in target regions and support a much extended 'northsouth' transfer of conservation resources that maximizes biodiversity conservation while mitigating global climate change.

\section{CONCLUSION and Future Sustainability Requirements}

Sustainability in agricultural practises is no more an option, and agriculture need to feed the growing billions in the earth's population. And the ever degrading environment needs protection and restoration. If sustainability is to be achieved, it has to happen in the market sector as well. This means that sustainability needs the support of all the market players in supply chain, and not only focus on the growers/producer.

RSPO now runs into its' sixth year of operation, and has some success in certifying plantations and mills. However, the next few years of it's' operation and milestone will show if it is indeed the path forward towards for sustainable agriculture. But, we can afford to fail with or without RSPO and other efforts by the industry similar to Malaysian Palm and ISPO should be given encouragement and support. Similar effort should be promoted in the rest of the oil palm world (Yew et al., 2010a).

\section{REFERENCES}

1. Aikanathan, S. (2010). "Roundtable on Sustainable Palm Oil." 17 March 2010 from http://en.wikipedia.org/wiki/Roundtable_on_S ustainable_Palm_Oil

2. Aikanathan, S., Chenayah, S., Sundram, K. and Sasekumar, A. (2011). ' Case study on sustainable eagriculture: A roudtable on Palm Oil", Paper presented at "Innovation and 
Sustainability Transitions in Asia Conference", http://umconference.um.edu.my/upload/1631/Paper\%2094.doc (not published)

3. Aljosja, H., Wösten, H., Silvius, H. and Page, S., (2006). Peat CO2. , Delft Hydraulics, Wetlands International

4. Fairtrade Foundation, (2010). http://www.fairtrade.org.uk/what_is_fairtrade/f airtrade_foundation.aspx (accesses on the $7^{\text {th }}$ Aptil 2011)

5. Greenpeace, (2010). 'Deforestation for Palm Oil',

http://www.greenpeace.org/usa/en/campaigns/f orests/forests-worldwide/paradise-

forests/palm-oil/ (accesses on the $7^{\text {th }}$ Aptil 2011)

6. Haas, (2009). Human Development: Report 2009 Overcoming barriers: Human Mobility and Develoment, in Human Development Research Paper Series, vol 01, N0. 2009.

7. Haq, M. U., (1990). Human Development Index, United Nations Development Programme, United Nations Development Programme's (UNDP) Human Development Reports (HDRs)

8. Jorgenson, A. K., Dick, K.C., and Austin, K., (2010). "The Vertical Flow of Primary Sector Exports and Deforestation in Less-Developed Countries: A Test of Ecologically Unequal Exchange Theory." Society \& Natural Resources Vol. 23 (Issue 9): 888-897, 810p

9. Jothiratnam, S. S. (2010). "Population, Energy, Food and Garbage: Their Potential Impact on Global Agriculture." Journal of Oil Palm \& The Environment 2010, 1:1-16 doi:10.5366/jope.2010.01 (1): 1-16

10. Laurance, W.F., (2007). 'Have we overstated the tropical biodiversity crisis?' , in Trends in ecology and Evolution 22 (2), pp 65-70.

11. Leahy, J. E. and Anderson, D.H., (2010). "“Cooperation Gets It Done": Social Capital in Natural Resources Management along the Kaskaskia River." Society \& Natural Resources Vol. 23 ( Issue 3): 224-239, 216p.

12. Lee, T. M. and Jetz, W., (2008). "Future battlegrounds for conservation under global change." Proc. R. Soc. B 275, 1261-1270

13. Persey, S. and Anhar, S., (2010). Biodiversity Information for Oil Palm. International Conference on Oil Palm and Environment. Bali, Indonesia.
14. Prescott-Allen, R., (2006). The structure of a wellbeing index. JRC/OECD Workshop, June 2006, Milano. Milano, http://www.unece.org/stats/documents/0000.00 .wgssd.htm.

15. Rada, N., (2010). 'Indonesian Agricultural Growth Leads to Increased Trade and Food Security', in Amber Waves Vol 8 (2), pp 4

16. Rodrigues G., Verwilghen A., Caliman J.P.. (2010). 'An Assessment Tool and Integrated Index for Sustainable Oil Palm Production' presented at the International Conference on Oil Palm and Environment 2010, Bali, INDONESIA.

17. RSPO (2008). 'Roundtable on Sustainable Palm Oil Promoting The Growth And Use Of Sustainable Palm Oil' ,http://www.rspo.org/files/resource_centre/RS PO_Fact_sheets_Basic.pdf (accessed 7 April, 2011)

18. Sheil, D.; Casson, A.; Meijaard, E.; van Noordwjik, M.; Gaskell, J.; SunderlandGroves, J.; Wertz, K.; Kanninen, M. (2009). The impacts and opportunities of oil palm in Southeast Asia: What do we know and what do we need to know? . Bogor, Indonesia, CIFOR. Occasional paper no. 51 .

19. Sodhi, N. S. (2008). "Tropical biodiversity loss and people - A brief review." Basic and Applied Ecology 9 9, 93-99.

20. Sodhi, N.S., Mary Rose, C. P., Lee, T.M., Bickford, D., Koh, L.P., and Brook, B.W., (2008). "The state and conservation of Southeast Asian biodiversity." Biodivers Conserv DOI 10.1007/s10531-009-96075,Environmental Conservation 35 (2): 160172

21. Solaridad, (2010). 'The Supply Chain Approach', http://www.solidaridadnetwork.org/supplychain-approach (accessed 7 April, 2011)

22. UNDP, 2006. World Population Prospects: The 2006 Revision. http://esa.un.org/unpp/, accessed March 27, 2010

23. UNEP (2007). The Last Stand of the Orangutan - State of emergency: illegal logging, fire and palm oil in Indonesia's national parks

24. Yew, F. K., Sundram, K. and Yusof Basiron. (2010a). "Mitigating Climate Change Through 
Malaysian Journal of Science 30 (1): 66-75 (2011)

Oil Palm Cultivation, " International Journal of Global Warming (IJGW) 2(No.2)

25. Yew, F. K., Sundram, K. and Yusof Basiron. (2010b). "Estimation of GHG Emissions from Peat Used for Agriculture with With Special Reference to Oil Palm ", Journal of Oil Palm \& The Environment 1 :17-25 doi:10.5366/jope.2010.02 1(1): 17-25. 